\title{
The Jijal Complex in the roots of the Kohistan island arc in the northwest Himalaya of Pakistan revisited
}

\author{
M Qasim J an†* and Barry L Weaver $\ddagger$ \\ † Department of Geology, University of Peshawar, Peshawar, PAKISTAN \\ ¥ School of Geology and Geophysics, University of Oklahoma, OK730911, USA \\ *To whom correspondence should be addressed.E-mail:mqjan@yahoo.com
}

The Kohistan Magmatic arc started building during the Early Cretaceous as an intra-oceanic island arc thousands of kilometers to the south of its present position. It was welded to the Karakoram plate along the Shyok suture during the midCretaceous, after which it became an Andean-type continental margin. Collision with India along the Indus suture occurred during the Early Eocene. The Kohistan arc exposes a complete section across the crust and consists of a range of variably metamorphosed plutonic, volcanic, and subordinate sedimentary rocks.

The lower crust in Kohistan is represented by a series of mafic to ultramafic rocks. These include the granulite facies metamorphosed Jijal complex, which covers $150 \mathrm{sq} \mathrm{km}$ area of the southern fringe of the arc along the Indus River. Relics of similar rocks in amphibolites also occur $35 \mathrm{~km}$ to the southwest, north of Shangla. The southern (structurally lower) part of the Jijal complex in the hanging wall of the Indus suture comprises chromite-layered dunites, peridotites, and pyroxenites. These pass upwards into garnet-bearing ultramafic and mafic granulites. The transition zone contains pyroxenites $( \pm \mathrm{Grt})$ or peridotites showing the development of garnet at the interface of plagioclase and opaque oxide /olivine.

The main bulk of the granulites is represented by the assemblage $\mathrm{Grt}+\mathrm{Px}+\mathrm{Pl}+\mathrm{Qtz}+\mathrm{Rt} \pm \mathrm{Hbl}$. These rocks are mostly homogeneous, but locally well-layered. In addition to the principal assemblage, the layers comprise garnet pyroxenites $(\mathrm{Cpx} \pm \mathrm{Opx} \pm \mathrm{Hbl})$, garnetites $( \pm \mathrm{Cpx} \pm \mathrm{Pl} \pm \mathrm{Hbl})$, and metaanorthosites represented by the assemblages $\mathrm{Pl}+\mathrm{Grt}+\mathrm{Cpx}+\mathrm{Scp}$ and $(\mathrm{Zo}+\mathrm{Grt} \pm \mathrm{Cpx} \pm \mathrm{Hbl} \pm \mathrm{Qtz})$. The northern part of the complex contains relics of gabbronorites/pyroxene granulites $(\mathrm{Pl}+\mathrm{Opx}+\mathrm{Cpx}+\mathrm{Hbl}+\mathrm{Ilm}+\mathrm{Mag})$ protolith. The garnet granulites here invade the protolith in networks of veins and patches that appear to have formed along joints and fractures due to release of $\mathrm{H} 2 \mathrm{O}$ during compression (increasing load pressure and temperature). Field data, combined with petrographic study and mineral analysis, suggest the following reaction for the transformation: $\mathrm{Pl}(\mathrm{An} 45)+\mathrm{Opx}(\mathrm{En} 62)+\mathrm{Cpx}(\mathrm{Mg} 33.8, \mathrm{Fe} 18.6, \mathrm{Ca}$ 47.6; $\left.\mathrm{Al}_{2} \mathrm{O}_{3} 7.2 \%, \mathrm{Na}_{2} \mathrm{O} 1.8 \%\right)+\mathrm{Prg}=\mathrm{Pl}(\mathrm{An} 48)+\mathrm{Grt}(\mathrm{Mg} 31.7, \mathrm{Fe} 44.9$, Ca 23.4)+Cpx(Mg 37.7, Fe 13.0, Ca 49.2; $\mathrm{Al}_{2} \mathrm{O}_{3} 5.6 \%, \mathrm{Na}_{2} \mathrm{O}$ 1.6\%)+Rt+Qtz. Jan et al. (1997) and Yamamoto and Yoshino (1998) showed that this transformation was isochemical for major elements. Further XRF data (Table 1) show that apart from a loss in soda, the major and trace elements remained immobile during the pyroxene-granulite to garnet granulite transition. When normalized to primordial mantle values, the analyses of the mafic granulites display island arc signatures (Figure 1).

The garnet granulites contain pods and elongated bodies (rarely exceeding a few tens of meters across) of hornblendites (commonly with Grt $\pm \mathrm{Cpx}$ ), garnetites $( \pm \mathrm{Cpx} \pm \mathrm{Pl} \pm \mathrm{Hbl}$ ), and pyroxenites $( \pm \mathrm{Gr} \pm \mathrm{Hbl})$. These are scattered throughout, but are

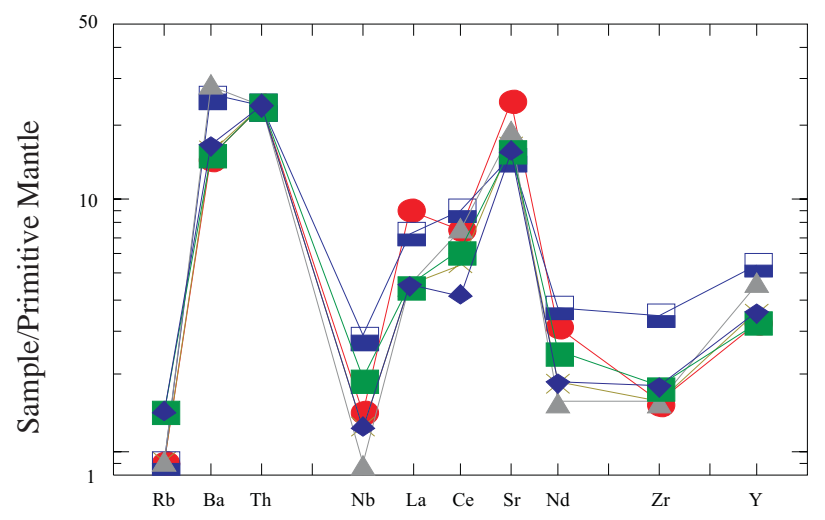

FIGURE 1. Mantle normalized analyses of the granulites

TABLE 1. XRF Analyses of Gabbronorite relic (1) and garnet granulite derivative (2)

\begin{tabular}{llllll}
\hline & 1 & 2 & & 1 & 2 \\
\hline $\mathrm{SiO}_{2}$ & 49.63 & 50.43 & $\mathrm{Zn}$ & 75 & 78 \\
$\mathrm{TiO}_{2}$ & 0.78 & 0.77 & $\mathrm{~V}$ & 247 & 269 \\
$\mathrm{Al}_{2} \mathrm{O}_{3}$ & 18.05 & 18.59 & $\mathrm{Zr}$ & 15 & 15 \\
$\mathrm{Fe} 0$ & 11.56 & 11.59 & $\mathrm{Nb}$ & 0.7 & 1.1 \\
$\mathrm{MnO}$ & 0.17 & 0.17 & $\mathrm{Rb}$ & $<1$ & $<1$ \\
$\mathrm{MgO}$ & 5.47 & 5.45 & $\mathrm{Sr}$ & 275 & 278 \\
$\mathrm{CaO}$ & 11.49 & 11.32 & $\mathrm{Ba}$ & 84 & 77 \\
$\mathrm{Na} 20$ & 2.65 & 1.47 & $\mathrm{Th}$ & $<2$ & $<2$ \\
$\mathrm{~K} O$ & 0.17 & 0.15 & $\mathrm{~Pb}$ & 3.6 & 3.4 \\
$\mathrm{P}_{2} \mathrm{O}_{5}$ & 0.05 & 0.05 & $\mathrm{La}$ & $<3$ & $<3$ \\
$\mathrm{Cr}$ & 29 & 29 & $\mathrm{Ce}$ & 6 & 9 \\
$\mathrm{Ni}$ & 12 & 10 & $\mathrm{Nd}$ & 3 & 4 \\
$\mathrm{Cu}$ & 30 & 24 & $\mathrm{Y}$ & 12 & 11 \\
\hline
\end{tabular}

particularly common in the southern part of the granulite terrain. It seems that the garnetites are metamorphosed intrusions of troctolite, allivalite, and olivine gabbros in the noritic hosts, a situation similar to that of the Chilas complex. Some of the hornblendites are intimately associated with the garnetites and there are local gradations between the two. Instead of proposing an origin by replacement (metasomatism), however, it is thought 
that they may also be magmatic intrusions (Yamamoto and Yoshino 1998), similar to those of Tora Tigga complex, $130 \mathrm{~km}$ to the southwest. Yamamoto and Nakamura (2000) have reported a younger Sm-Nd metamorphic age (83 Ma) for the garnet hornblendites than for the garnet granulites (96-90 Ma). But these dates have to be taken cautiously. The granulites, garnetites, garnet hornblendites, and $\mathrm{Grt}+\mathrm{Cpx}+\mathrm{Hbl}$ veins in the latter yield similar PT estimates $\left(750-900^{\circ} \mathrm{C}, 11-15 \mathrm{kbar}\right.$; Jan and Howie 1981, Yamamoto 1993). It is likely that all these bodies were emplaced before the peak metamorphic conditions of the high-pressure granulite facies were attained in the deep levels of the thickened arc. It is tempting to postulate that the thickening is related to collision along the Shyok suture, which resulted in overthrusting of the Karakoram plate onto the Kohistan arc. But the timing of this collision is poorly constrained and presumed to have occurred between 75 and $100 \mathrm{Ma}$ ago. Therefore, alternate hypotheses for crustal thickening (dragging down of the complex along the Main Mantle Thrust; imbrication and thrusting in the frontal arc; continued magmatism) should not be summarily discarded.

During cooling and uplift, the Jijal complex was locally hydrated, especially in shear zones and along fractures. This resulted in the development of a range of amphibolite facies and greenschist facies assemblages. These include $\mathrm{Ky}+\mathrm{Zo}+\mathrm{Pg}+\mathrm{Crn}$ (after meta-anorthosites), and $\mathrm{Hbl} \pm \mathrm{Pl} \pm \mathrm{Grt} \pm \mathrm{Ep} \pm \mathrm{Pg}$ and Act+Chl+Ep+Ab (after mafic rocks).

\section{References}

Jan MQ and RA Howie. 1981. The mineralogy and geochemistry of the metamorphosed basic and ultrabasic rocks of the Jijal complex, Kohistan, NW Pakistan. J Petrol 22: 85-126

Jan MQ, BL Weaver and BF Windley. 1997. Summarised petrology of the garnet granulites of the Jijal complex, Kohistan Himalaya. Abs $3^{\text {rd }} \mathrm{Pak}$ Geol Cong Peshawar: 29-30

Yamamoto H. 1993. Contrasting metamorphic P-T paths of the Kohistan granulites and tectonics of the western Himalaya. J Geol Soc London 150: 843-856

Yamamoto H and E Nakamura. 2000. Timing of magmatic and metamorphic events in the Jijal complex of the Kohistan arc deduced from Sm-Nd dating of mafic granulites. In: Khan MA, PJ Treloar, MP Searle and MQ Jan (eds) Tectonics of the Nanga Parbat Syntaxis and the Western Himalaya. Geol Soc London Spec Publ 170: 313-319

Yamamoto H and T Yoshino. 1998. Superposition of replacements in the mafic granulites of the Jijal complex of the Kohistan arc, northern Pakistan: dehydration and rehydration within deep arc crust. Lithos 43: 219-234 